УДК 78.03+78.087(784.5)

DOI https://doi.org/10.31723/2524-0447-2021-32-2-14

Юрій Степанович Кучурівський

ORCID: 0000-0003-0007-8636

кандидат мистецтвознавства, старший викладач кафедри хорового диригування

Одеської національної музичної академії імені А. В. Нежданової yskuchurivskyy@ukr.net

\title{
ВИКОНАВСЬКІ АСПЕКТИ ХОРОВОЇ МУЗИКИ ХХ СТОЛІТТЯ НА ПРИКЛАДІ «КЕЛЬТСЬКОГО РЕКВІЕМУ» ДЖ. ТАВЕНЕРА
}

Мета роботи полягає у визначенні основних проблемних напрямів виконавського освоєння «Кельтського реквієму» Дж. Тавенера як показового прикладу хорової музики XX сторіччя. Методологія дослідження спирається на комплексне використання системного методу (для визначення окремих елементів музичної мови і прийомів музичної виразності як компонентів художньої иілісності музичного твору); методу музикознавчого стильового аналізу (під час розгляду стильовоі специфіки твору Дж. Тавенера); хорознавчого методу (що задіяний для визначення основних методичних прийомів і принципів роботи хорового колективу і хормейстера над виконавськими труднощами сучасної хорової музики). Наукова новизна дослідження зумовлена спеціальною хорознавчою спрямованістю вивчення «Кельтського реквієму» Дж. Тавенера як видатного зразка хорової музики ХX століття. Результати дослідження поглиблюють уявлення про методичні аспекти хорового стилю композиторів - репрезентантів музичного мистецтва XX століття, що становить актуальний напрям сучасної виконавської практики. Висновки. У контексті загальних стильових засад хорового стилю «Кельтського реквієму» Дж. Тавенера розглянуто специфіку виконавської техніки, що пов'язана з особливостями сучасного хорового стилю. Виокремлено низку спеціальних виконавських прийомів, що є характерними для хорової сонористики: мовне інтонування, глісандо, кластер. Визначено основні завдання та труднощі технічного характеру, що виникають у процесі практичного освоєння хормейстером і співаками хорової партитури «Кельтського реквієму». Особливу увагу приділено проблемі хорового інтонування як того чинника, що забезпечує повноцінне художне втілення композиторського задуму. Запропоновано низку методів, спрямованих на подолання цих труднощів (аналіз мобільних i варіативних компонентів хорової партитури з метою визначення їхніх драматургічних функцій, робота над імпровізаційними структурами

(C) Кучурівський Ю. С., 2021 
музичного тексту $i$ «мотивною інтонацією»). Акцентується увага на необхідності спеціального теоретичного аналізу хорової партитури 3 метою виявлення тих параметрів, що дозволяють адекватно оцінити логіку формування виконавської інтерпретації та принцип відбору прийомів хорової техніки, необхідних для втілення художньої концепції mвору.

Ключові слова: Джс. Тавенер, авангардний стиль, хоровий стиль, хорова інтонація, техніка хорового співу, інтонування, сонористика, композиційна техніка.

Kuchurivsky Yurii Stepanovych, Ph.D. in History of Arts, Lecturer at the Department of the Choral Conducting of the Odessa National A. V. Nezhdanova Academy of Music

Performing aspects of twentieth-century choral music on the example of “Celtic Requiem” by J. Tavener

The purpose of the article is to identify the main problem areas of performing mastery of J. Tavener's "Celtic Requiem" as an illustrative example of choral music of the 20th century. The research methodology is based on the complex use of the systemic method (to determine the elements of the musical language and the techniques of musical expressiveness characteristic of the style concept of J. Tavener's “Celtic Requiem”), the method of musical style analysis (when considering the style specifics of J. Tavener's composition), the choral method (to determine the basic methodological techniques and principles of the work of the choir collective and the choirmaster on the performing difficulties of the work). The scientific novelty of the research is due to the special choral orientation of the study of the "Celtic Requiema by J. Tavener as an outstanding example of choral music of the 20th century. The results of the study deepen the understanding of the methodological aspects of the choral style of the composers-representatives of the musical art of the 20th century, which is the current direction of modern performing practice. Conclusions. In the context of the general stylistic attitudes of the choral style of "Celtic Requiem" by J. Tavener, the specificity of the performing technique associated with the peculiarities of the modern choral style is considered. A number of special performing techniques characteristic of the choral style of J. Tavener and its sonoristic features are highlighted: speech intonation, glissando, cluster, noise effects. The main tasks and difficulties of a technical nature that arise in the process of mastering the choir score of the "Celtic Requiem" by the choirmaster and singers are determined. Special attention is paid to the problem of choral intonation as the main factor providing a full-fledged artistic embodiment of the composer's intention. A number of methods are proposed to overcome these difficulties (analysis of the mobile and variable components of the choral score in order to determine their dramatic functions, work on the improvisational structures of the musical text and "motivational intonation"). Attention is focused on the need for a special theoretical analysis of the choral score in order to identify a number of parameters that will allow adequately assessing the logic of the formation of a performing interpretation and the principle of 
selecting the techniques of choral technique necessary for the embodiment of the composer's intention.

Key words: J. Tavener, avant-garde style, choral style, choral intonation, technique of choral singing, intonation, sonoristic, compositional technique.

Актуальність теми дослідження. Хоровій музиці Дж. Тавенера належить провідне місце в сучасному хоровому виконавстві, тому вона потрібує спеціального музикознавчого i виконавського дослідження. Завдяки своїм стильовим особливостям «Кельтський реквієм» (1968 р.) Дж. Тавенера висуває перед виконавцями низку практичних завдань та вимог, шо пов'язані зі специфікою музичної мови даного твору, яка принципово відрізняється від традиційних норм класичної європейської хорової музики. Використання у творі Дж. Тавенера композиційно-технічних прийомів додекафонії, алеаторики та сонористики забезпечило новий рівень музичної виразності і нові засоби вокально-хорової техніки. Стильова специфіка таких музичних опусів виключає мелодію як основний виразний елемент музичної мови, іiі заміняють більш складні явища на кшталт кластера, шумових ефектів і різних музичних структур, що не інтонуються.

Виконавське освоєння «Кельтського реквієму» Дж. Тавенера як яскравого і показового прикладу хорової музики XX ст. вимагає вивчення його стилістики та спеціальних методів іiі практичного опанування. Тому звернення до даної теми зумовлено актуальними запитами сучасного хорового виконавства і має безпосередню практичну цінність. Актуальність теми даного дослідження зумовлена також і малим ступенем популярності хорової музики Дж. Тавенера серед українських музикантів, професійна діяльність яких сьогодні з успіхом інтегрується у світовий музично-виконавський процес.

Мета дослідження полягає у визначенні основних проблемних напрямів виконавського освоєння «Кельтського реквієму» Дж. Тавенера як показового прикладу хорової музики XX ст.

Наукова новизна дослідження зумовлена спеціальною хорознавчою спрямованістю вивчення «Кельтського реквієму» Дж. Тавенера як видатного зразка хорової музики $\mathrm{XX}$ ст. Результати дослідження поглиблюють уявлення про методичні аспекти хорового стилю композиторів - репрезентантів музичного мистецтва XX ст., що становить актуальний напрям сучасної виконавської практики. 
Методологія дослідження спирається на комплексне використання системного методу (для визначення окремих елементів музичної мови і прийомів музичної виразності як компонентів художньої цілісності музичного твору); методу музикознавчого стильового аналізу (у розгляді стильової специфіки твору Дж. Тавенера); хорознавчого методу (що задіяний для визначення основних методичних прийомів і принципів роботи хорового колективу і хормейстера над виконавськими труднощами сучасної хорової музики).

Виклад основного матеріалу. У «Кельтському реквіємі» Дж. Тавенер звернувся до великого виконавчого складу, що надало композитору дуже великих можливостей музично-художньої виразності. Так, у творі задіяні три хори, солісти і дитячий хор, які утворюють розвинену вокально-хорову фактуру для якої характерні поліпластовий принцип організації та динамічний і темповий контрасти, а також рельєф сонористичної щільності звучання. В інструментальному складі «Кельтського реквієму» - кларнет, басовий тромбон, труба пікколо, великий орган, фортепіано, електрогітара, струнні, група перкусії й ірландська волинка. Такий специфічний у тембровому відношенні інструментальний ансамбль, що був притаманний авангардистським пошукам Дж. Тавенера на початку його творчого шляху, надає його твору дуже яскравого архаїчно-ритуального колориту.

Авангардистська складність музичної мови «Кельтського реквієму» зумовила такі особливості його вокально-хорової фактури, як: різноманітність звукової щільності, сонористичні ефекти (шепіт, говір тощо), фонетичні «напливи» тексту, хорова педаль, дуже рухливий динамічний рельєф, звукозображальні прийоми. Усі ці тонкощі хорового звучання зафіксовані в партитурі за допомогою нотної графікі, що притаманна класичним зразкам музичного авангарду середини XX ст. і яка рясніє вказівками на тривалість часових відрізків, у яких звучить повторюваний музичний тематизм, i авторськими ремарками щодо характеру виконання. Водночас наголошуємо на головному ефекті, якого досягає композитор завдяки всім цим прийомам хорового звучання: власне сам вербальний текст, який звучить у хору, втрачається в загальній звуковій масі, від нього часто залишаються тільки сонористичні відгомони. Зміст тексту, який озвучує хор, не завжди можна вловити, тоді як текст, який доручено дитячому хору, 
протягом усієї композиції звучить чітко і ясно, врізаючись у пам'ять слухачеві. Цей ефект досягається, безумовно, за допомогою максимального контрасту тематизму дорослих хорів та солістів (складного в мелодико-інтонаційному відношенні) та дитячого хору (украй примітивного й одноманітного).

Хорові твори, що написані в композиційних техніках XX ст. (додекафонія, сонористика, алеаторика, мікрополіфонія, нова тональність, модальність, формульна композиція тощо), викликають певні складності у плані виконавської техніки. Для авангардного напряму хорової музики другої половини XX ст., до якого належить «Кельтський реквієм» Дж. Тавенера, характерні дисонуючі співзвуччя, вільна хроматика і вільний ритм, розмаїття сонористичних прийомів. До цього напряму належать не тільки серійні та сонористичні композиції, а й твори, що представляють «нову тональну» музику, у якій змістовний смисл літературного тексту виражений новаторськими музичними засобами (хорові опуси К. Пендерецького, Л. Ноно, Д. Лігеті, Дж. Тавенера й інших) [7].

Особливі виконавські труднощі доставляє «нова» авангардна музична мова партитури «Кельтського реквієму»: у ній досить гармонійної складності, складних звукосполучень, дисонуючих співзвуч, вільна хроматика, безліч особливих властивостей і прийомів артикуляції тощо. Хорове письмо XX ст. включає до своїх виразних засобів складну вокально-хорову техніку і фактуру, нестандартні із класичного погляду гармонійні з'єднання, метроритмічні, штрихові, дикційні складності тощо. Усе це висуває нові завдання і вимоги у виконавській діяльності: необхідні фахівці, які добре знають естетичні та теоретичні основи сучасного хорового мистецтва і володіють виконавською практикою. Сучасні хорові партитури вимагають від хорових співаків вільного володіння інтонацією, освоєння складних інтервалів, інтелектуального й емоційного осмислення музичного твору. Від хормейстера потрібне розуміння художньої ідеї твору, високий рівень диригентської техніки, уміння вирішити проблеми дихання і дикції, різноманітних звукових ефектів.

Для виконавської інтерпретації «Кельтського реквієму» Дж. Тавенера виняткове значення має проблема інтонування, що зумовлено складністю мелодійної мови даного твору. У зв'язку із цим особливої актуальності для практичного виконавського освоєння даного твору набуває концепція 
зонної природи слуху, що була розроблена М. Гарбузовим [2]. Згідно з ії основними положеннями, співаки повинні користуватися зонним ладом, але водночас усвідомлювати, що «зона» - це не тільки суто теоретичне поняття, абстрактне вираження висоти звуку, але й реальне уявлення про інтонацію. Прикладом практичного застосування цих уявлень може стати робота над так званою «мотивною інтонацією» як складовою частиною хорового інтонування: цей метод дозволяє виконувати складні в мелодико-інтонаційному плані хорові твори за допомогою членування складних мелодійних ліній на прості, звичні слуху мотиви.

Аналізуючи різноманітні аспекти хорової інтонації, А. Лащенко зазначає: «Головне, на чому зосереджує увагу співаків керівник, - це кінетична спрямованість мелодійного малюнку, тобто тут панує внутрішня настройка співаків на інтонування фрагмента як комплексу <..> Так, на основі попереднього розбору тематичного матеріалу він практикує «вичленення» 3 контексту вузлових, найбільш характерних інтонацій і спів їх усім хором, створюючи тим самим потрібний динамічний настрій на інтонування «опор» усієї конструкції музичної тканини» [3, с. 95]. Даний метод не може бути універсальним, але він охоплює основні проблеми технології хормейстера, що є необхідною для виконання творів сучасних композиторів. Аналізуючи прийоми хорової виразності в музиці XX ст., Е. Білявський говорить про проблему освоєння інтонаційних труднощів, пов'язаних з інтонуванням акордів-співзвуч, що є надзвичайно актуальним для хорової партитури «Кельтського реквієму» [1, с. 18]. До таких належать кластери і нефункціональні гармонійні комплекси, які є основним атрибутом хорового стилю другої половини XX ст. загалом і твору Дж. Тавенера зокрема.

Так, друга частина «Кельтського реквієму» являє собою яскравий приклад авангардистського стилю раннього періоду творчості Дж. Тавенера, що надає партитурі надзвичайної музично-тематичної багатошаровості: вона складається 3 окремих тематичних блоків, які накладаються один на одного й утворюють сонористичний звуковий простір із різних тембрів, ритмів, мелодійних утворень. Щільність фактури утворюється переважно хоровим звучанням (використовуються всі три хори), у якому застосований прийом скандування дрібними нотами без слів ("bombarde” у позначенні Дж. Тавенера). 
Цей пласт поєднується з гострим ритмом тромбона, різкими акордами струнних інструментів, «колючих» розкиданих звуків у труби, остинатним звучанням перкусії. Усі ці тематичні лінії утворюють в комплексі звуковий ефект хаосу, який втілює картину Судного дня. I контрастом до цієї «музичної картини» виступає дитяча гра, яка в символічній формі представляє шлях душі до чистилища. Звучання «дорослих» хорів потребує досконалого інтонування, завдяки якому вибудовується той сонористичний простір, що протиставляється простоті дитячого хору.

Для досягнення чистоти інтонації в даному разі доцільно використовувати метод роботи над хоровою інтонацією Е. Білявського, який, як відомо, поділяється на кілька етапів. Перший етап - це підготовчі вправи на класичному матеріалі, повторення і закріплення «традиційних норм інтонування». На цьому етапі потрібно домагатися чистого інтонування всіх видів мажорних, мінорних і хроматичних гам. Наступний етап спрямований на інтонування народних ладів і пентатоніки. Далі потрібно переходити до співу тетрахордів (цей етап спрямований на відпрацювання вільного інтонування малих інтервалів). I тільки потім можна переходити до точного інтонування хроматичних комплексів. Для відпрацювання навичок інтонування складних акордових співзвуч можна рекомендувати використовувати більш простий музичний матеріал дисонуючого звучання (різні хорові голоси співають гаму в інтервал кварти, квінти, секунди в паралельному напрямі). Також можна застосувати метод звуковисотного нашарування. Ці методи, на думку Е. Білявського, дозволяють хоровим співакам подолати функціонально-гармонійне мислення, швидко переорієнтуватися і співати політональні, серійні та сонористичні твори [1, с. 17].

До числа характерних прийомів хорового письма Дж. Тавенера належить послідовне нашарування хорових партій, коли в результаті розвитку всіх голосів виникає акордове співзвуччя. У такому разі виникають деякі інтонаційні незручності, вирішити які можна шляхом хорового співу тієї мелодії, що з'являється в результаті послідовного нашарування різних голосів. Поступове засвоєння загальної мелодійної лінії всіма учасниками хорового колективу дуже корисно, тому що допомагає уявити собі іiі розвиток загалом, зокрема того звуковисотного співвідношення, що виникає між початковим звуком 
їхніх партій та попереднім звуком іншої партії. Це сприяє чистоті інтонування, своєчасному вступу голосів. Позитивні результати також дає прийом «уявного виконання» мелодійної лінії в повному обсязі.

У «Кельтському реквіємі» хорова фактура або один із іiі пластів часто складається 3 паралельного звучання різних гармонійних комплексів. Паралелізм чистих кварт, квінт, різних дисонуючих інтервалів ставить перед виконавцями більш складні завдання, ніж таке ж виконання терцій, секст. Сприяє цьому активний розвиток політональної гармонії в музичному мисленні XX ст. Авангардна стилістика твору Дж. Тавенера складається з досить складної вокальної мелодики та гармонійної мови, фактурних нашарувань, метроритмічних, штрихових та дикційних складнощів. На думку дослідників хорового мистецтва, коли співаки усвідомлюють виправданість усіх технічних складнощів, їхню художню функцію, то виникає інтерес до їх подолання для досягнення усвідомленого художнього результату [3; 5].

Як бачимо, хоровий стиль Дж. Тавенера вимагає від співаків високого рівня вокально-ансамблевої виконавської техніки: поряд із кантиленою у творі наявні експресивні інструментальні лінії, із плавним голосоведінням - «ламана» мелодія, поряд із мелодійною інтонацією - репліки, декламації, драматичні вигуки. Ускладнення мови сучасного хорового стилю, застосування нових засобів в області гармонії, ритму створюють основу для творчого і професійного зростання виконавців, для розширення їхнього музичного та художнього світогляду.

Широко застосовуються Дж. Тавенером усілякі сонорні прийоми: їхні характерні особливості походять 3 архаїчних витоків хорового співу, тих спеціальних прийомів, що створюють фонізм хорової фактури (приблизна висота тону, глісандо, манера інтонування, що відрізняється від академічного співу, мовна інтонація, гетерофонічна фактура). Насичуючи хорову фактуру сонорними прийомами, композитори-авангардисти ставили перед собою мету розширення виражальних можливостей людського голосу і пошуку нового тембрового колориту хорового звуку.

Ц. Когоутек визначає сонористику як «музику тембрів», яка оперує «звуковими-тембровими пластами і лініями» [4, с. 236]. У музичній теорії XX ст. також є ціла низка термінів, 
які можуть застосовуватися для визначення суті сонористики як виду композиторської техніки: «статична композиція» (К. Штокхаузен), «музика звучностей» (Р. Фікер, Р. Траймер). Шодо хорової музики сонористику найчастіше розглядають як прояв колористичної тенденції в розвитку музичної мови XX ст., тому П. Левандо, наприклад, говорить про колористичні прийоми хорового стилю і згадує спів басів-октавістів, спів із закритим ротом, спів на голосних звуках, спів на постійно повторюваних складах та їх поєднаннях, «відлуння», фальцет, а також глісандо, кластер, мелодекламацію і шумові ефекти (крик, шепіт, клацання мовою, схлипи, видих тощо) [5, с. 23]. У мовному інтонуванні зазвичай виділяють два основні різновиди: сонорну мовну інтонацію, що організована за допомогою метру, ритму і приблизної звуковисотності, та мелодійну сонорну мовну інтонацію, що є проміжною між мовною та музичною.

Мовне інтонування надає композиторам можливість збагачувати фактуру твору досить неординарним способом виразності, нерідко для підкреслення образного смислу вербального тексту. Шумові ефекти, що застосовуються композиторами в хоровій музиці, дають можливість передати слухачеві картину того, що відбувається в музиці, більш яскраво і реалістично. Шумові ефекти завдяки своїй образотворчості здатні більш точно передати настрій, атмосферу місця або ж діiі, що мається на увазі композитором. 3 появою шумових ефектів у хоровій музиці з'явилися нові можливості використання тих звучань, що не інтонуються та забезпечують оригінальність хорового звуку. Щодо такого сонорного прийому, як глісандо, наприклад, необхідно відзначити, що його функція дуже часто пов'язана в хоровій музиці XX ст. 3 функцією посилення вираження різних емоційно-психологічних станів. А кластер являє собою такий прийом, що утворює ефект злиття різних тембрів. Сам собою цей прийом неймовірно багатий у тембровому відношенні, тому що об'єднує в собі різні тембри голосу кожного виконавця і передає широкий спектр звучання загалом. Найчастіше композитори використовують кластер для створення ефекту несподіванки в музичній композиції, «розбавляють» тим самим загальну фактуру звучання. Досить часто кластер виконує функцію або фонової підтримки солюючої партії, або ж функцію особливого психологічного забарвлення. 
Існує специфіка виконавської роботи як хорових співаків, так і хормейстера у процесі роботи над хоровою партитурою, у якій використовується сонористична техніка. Передусім це стосується різноманітності диригентського жесту: адже хормейстер змушений відходити від усіх традиційних жестів, щоб адекватно «перевести» графіку хорової партитури в хорове звучання. Хормейстер змушений також проводити детальне опрацювання твору з хором аж до пояснень найдрібніших деталей хорової партитури. Тим самим увага хормейстера має бути зосереджена на аналізі методологічних і теоретичних основ сучасної композиції та їх подальшої інтерпретації.

У багатьох сонорних хорових прийомах (глісандо, скандування, вигук, шепіт) використовується виконавська імпровізація, що становить важливий та спеціальний принцип сучасної хорової техніки. Історичний розвиток вокально-хорового мистецтва показує, що можна виділити такі чинники, що визначають суть вокально-хорової імпровізації. Перший взаємодія музики і поезії, що визначило синтетичний принцип вокально-хорової музики. Поетична інтонація, слово в музичному творі виступає в ролі повноправного учасника художньої цілісності музичного твору. Слова і звуки, його складові частини, повинні нести в собі емоційний і психологічний смисл. Тому вокально-хорова імпровізація передбачає володіння як музичною імпровізацією, так і словесною, поетичною, інтонаційною в широкому сенсі. Другий, пов'язаний 3 аксіоматичним положенням про те, що основним «інструментом» вокально-хорового мистецтва $є$ людський голос. Отже, для вокально-хорової імпровізації необхідно володіти вокально-хоровими виконавськими навичками: почуттям ладового тяжіння, метроритмічною стійкістю, інтонаційною свободою, володінням співочим диханням та тембровою палітрою, розвиненим вокальним і зонним слухом, розвиненим діапазоном звучання голосу, ансамблевими навичками тощо. Третій зумовлений пластичною складовою частиною музичного виконавства: виконання вокально-хорової музики неможливо без участі в цьому процесі міміки, рухів рук і тіла. Вокаліст-виконавець - це актор, який володіє всією палітрою образного перевтілення, у якому бере участь усе його тіло. Це утворює сценічний образ вокально-хорового виконавського мистецтва. 
С. Мальцев, досліджуючи допустиму зону творчої свободи виконавця в сучасній нотації, виділяє графічні знаки, що відображають об’єктивні уявлення композитора про звучання твору (звуковисотність, метроритм), і знаки, що відображають суб'єктивні уявлення композитора про звучання твору (інтонація як психологічна забарвленість музичного матеріалу, тембр, дихання, фразування, штрихи, агогіка тощо) [6, с. 88]. У музичній нотації сучасних партитур автор розділяє інваріантні та варіативні способи фіксації музики. Цей момент необхідно враховувати і хормейстеру в освоєнні сучасної хорової музики. Під час роботи з хоровою партитурою виконавцю доцільно провести іiі аналіз із метою виявлення низки параметрів, що дозволять адекватно оцінити логіку формування виконавської інтерпретації і принцип відбору прийомів хорової техніки, необхідних для втілення композиторського задуму. Такими параметрами є: мобільність форми, мобільність звуковисотного матеріалу, мобільність ритмічного малюнку; особливості графічної фіксації нотного тексту; вокальна і вербальна складові музичного тексту; певна звуковисотність і приблизна; чисте інтонування й інтонування із призвуком дихання; конкретні прийоми авангардних композиційних технік; наявність авторських приписів щодо застосування виконавської імпровізації у творі; наявність авторських ремарок, що несуть драматургічне навантаження. Тобто в сучасній хоровій музиці виконавцю надається велика свобода інтерпретації музичного тексту, у прояві свого індивідуального розуміння композиторського задуму. Це впливає не тільки на художню цілісність твору, але і на деталі, складники музичного цілого.

Висновки. Стилістика «Кельтського реквієму» Дж. Тавенера $€$ показовою для хорової музики XX ст., іiі авангардистські витоки зумовили деяку складність хорової партитури даного твору, що пов'язана з використанням сучасної техніки музичної композиції. Це зумовлює низку проблемних напрямів виконавського освоєння твору Дж. Тавенера (чистота хорового інтонування, опанування сонорних прийомів, імпровізаційна техніка тощо), які є наслідком спільності стильових принципів хорового письма видатного представника британської музики зі стильовими засадами сучасної хорової музики і викликають необхідність визначення конкретних шляхів подолання технічних труднощів у процесі 
роботи над твором. Розглянуті спеціальні прийоми хорової сонористики (глісандо, кластер, мовне інтонування), а також загальна стильова специфіка музичної мови «Кельтського реквієму» зумовлюють застосування низки методів, що спрямовані на подолання цих труднощів (аналіз мобільних і варіативних компонентів хорової партитури з метою визначення їхніх драматургічних функцій, робота над імпровізаційними структурами музичного тексту і «мотивною інтонацією»).

\section{СПИСОК ЛІТЕРАТУРИ}

1. Білявський Е. Засвоєння сучасної музичної мови в хорі. Київ : Музична Україна, 1984. 40 с.

2. Гарбузов Н. Внутризонный интонационный слух и методы его развития. Москва : Музгиз, 1951. 64 с.

3. Лащенко А. Хоровая культура: аспекты изучения и развития. Киев, 1989. 132 с.

4. Когоутек Ц. Техника композиции в музыке XX в. Москва : Музыка, 1976. 266 с.

5. Левандо П. Хоровая фактура : монография. Ленинград : Музыка, 1984. 123 с.

6. Мальцев С. О психологии музыкальной импровизации. Москва : Музыка, 1991. 88 с.

7. Петров В. Реквием и современность. Израиль ХХІ: музыкальный жмунал. URL: http://www.21 israel-music.com/Petrov_Rekviem_ XX.htm (дата звернення: 17.04.2021).

\section{REFERENCES}

1. Biliavskyi, Y. (1984). Acquisition of modern musical language in the choir. Kiev: Muzychna Ukraina [in Ukrainian].

2. Garbuzov, N. (1951). Intrazonal intonation hearing and methods of ear training. Moscow, Leningrad : Muzgiz [in Russian].

3. Lashenko, A. (1989). Choral culture: aspects of study and development. Kiev : Muzychna Ukraina [in Russian].

4. Kogoutek, C. (1976). Compositional technique in 20'th century music. Moscow : Music [in Russian].

5. Levando, P. (1984). Choral texture. Monograph. Leningrad: Music [in Russian].

6. Malcev, S. (1991). About the psychology of musical improvisation. Moscow: Music [in Russian].

7. Petrov, V. (2010). Requiem and modernity. Israel XXI: music magazine. URL: http://www.21israel-music.com/Petrov_Rekviem_ XX.htm [in Russian]. 